\title{
Simple Syntheses of Two New Benzo-Fused Macrocycles Incorporating Chalcone Moiety
}

\author{
Rina Mondal, Swati Samanta, Saheli Sarkar, and Asok K. Mallik \\ Department of Chemistry, Jadavpur University, Kolkata 700 032, India \\ Correspondence should be addressed to Asok K. Mallik; mallikak52@yahoo.co.in \\ Received 28 June 2014; Revised 27 September 2014; Accepted 3 October 2014; Published 29 October 2014 \\ Academic Editor: Virinder S. Parmar \\ Copyright (C) 2014 Rina Mondal et al. This is an open access article distributed under the Creative Commons Attribution License, \\ which permits unrestricted use, distribution, and reproduction in any medium, provided the original work is properly cited. \\ Simple syntheses of the benzo-fused 26-membered macrocyclic bischalcone (19E,43E)-2.11.27.36-tetroxaheptacyclo[44.4.0.0 ${ }^{4,9}$. \\ $0^{12,17} \cdot 0^{21,26} \cdot 0^{29,34} \cdot 0^{37,42}$ ]pentaconta-1(46),4(9),5,7,12(17),13,15,19,21,23,25,29,31,33,37,39,41,43,47,49-icosaene-18,45-dione (3) and the \\ benzo-fused 13-membered macrocyclic chalcone (19E)-2.11-dioxatetracyclo[19.4.0.0 $\left.0^{4,9} \cdot 0^{12,17}\right]$ pentacosa-1(25),4(9),5,7,12(17),13, \\ 15,19,21,23-decaen-18-one (5) using very common starting materials and reagents are described. The compounds are new and they \\ have been characterized from their analytical and spectral data.
}

\section{Introduction}

Chalcones (1,3-diphenyl-2-propen-1-ones) [1] are known to possess a range of important biological activities, such as antibacterial [2], antifungal [3], antileishmanial [4], antimalarial [4], antifilarial [5] anti-inflammatory [6-8], antiprotozoal (antileishmanial and antipanosomal) [9], antimicrobial [10-13], larvicidal [14], anticonvulsant [15], anti-HIV [16], antitumor [17], and anticancer [18] activities, and they could be readily transformed into varieties of other compounds, many of which are biologically active heterocycles $[19,20]$. Owing to such biological activities of chalcones, the chemical literature shows the synthesis of a wide range of chalcones and their analogues [4, 8-13, 21-23]. Again, since macrocyclic compounds are well-known for their ability to show the important property of molecular recognition, macrocyclic systems containing the chalcone moiety are expected to generate compounds having interesting biological and material properties [24, 25]. Our research on such compounds has been initiated through the synthesis of a number of macrocyclic bis- and monochalcones reported recently [26]. In continuation of that study we have synthesized a benzo-fused 26-membered macrocyclic bischalcone, namely, (19E,43E)-2.11.27.36-tetroxaheptacyclo [44.4.0.0 $\left.0^{4,9} \cdot 0^{12,17} \cdot 0^{21,26} \cdot 0^{29,34} \cdot 0^{37,42}\right]$ pentaconta-1(46),4(9),5, $7,12(17), 13,15,19,21,23,25,29,31,33,37,39,41,43,47,49$-icosaene- 18,45-dione (3), and a benzo-fused 13-membered macrocyclic monochalcone, namely, (19E)-2.11-dioxatetracyclo[19.4.0. $\left.0^{4,9} \cdot 0^{12,17}\right]$ pentacosa-1(25),4(9),5,7,12(17),13,15,19,21,23-decaen-18-one (5), by use of readily available starting materials. Herein we report the synthesis of these two hitherto unknown compounds.

\section{Results and Discussion}

Alkylation products of salicylaldehyde and $o$-hydroxyacetophenone by the use of 1,2-(bis-bromobenzyl)benzene as alkylating agent were first prepared. The resulting dialdehyde (1) and diketone (2), both new compounds, were then subjected to Claisen-Schmidt reaction under high dilution condition when the macrocyclic bischalcone $\mathbf{3}$ was obtained in moderate yield (Scheme 1). In order to achieve the synthesis of 5,2,2'-dihydroxychalcone (4) was first constructed from $o$-hydroxyacetophenone and salicylaldehyde by Claisen-Schmidt reaction. The reaction between 4 and 1,2(bis-bromobenzyl)benzene was then done by following the typical procedure for alkylation of phenols $\left(\mathrm{K}_{2} \mathrm{CO}_{3}\right.$ /acetone, reflux, $12 \mathrm{~h}$ ) (Scheme 2). This reaction gave 5 in very good yield and no trace of any macrocyclic bischalcone 7 (a possible product through bimolecular cyclization of the intermediate 6) (Scheme 3). 


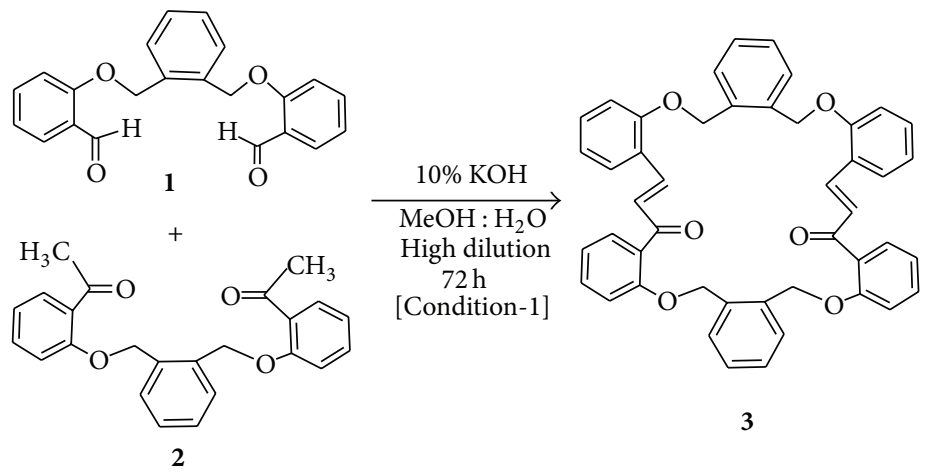

Scheme 1: Synthesis of the macrocyclic bischalcone 3 .
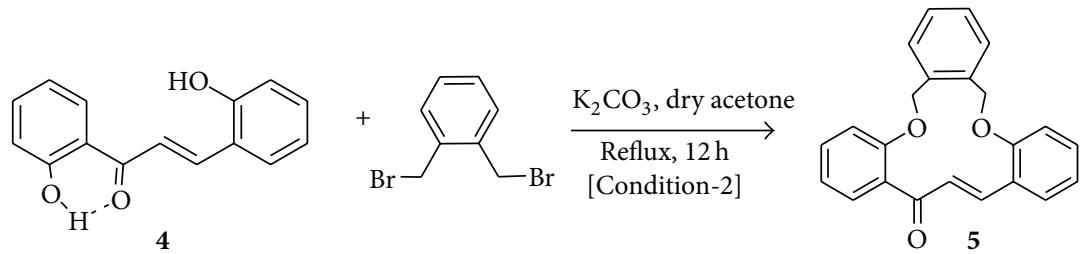

SCHeme 2: Synthesis of the macrocyclic monochalcone 5.

The new compounds $\mathbf{3}$ and $\mathbf{5}$ were characterized from their analytical and spectral data which are presented in the Experimental Section as well as in the Supplementary File in the Supplementary Material available online at http://dx.doi.org/10.1155/2014/485014.

\section{Experimental}

Melting points were taken in open capillary tubes and are uncorrected. IR spectra were recorded on a Perkin Elmer FT-IR spectrophotometer (Spectrum BX II) in $\mathrm{KBr}$ pellets. ${ }^{1} \mathrm{H}$ and ${ }^{13} \mathrm{C} \mathrm{NMR}$ spectra were recorded in $\mathrm{CDCl}_{3}$ on a Bruker AV-300 (300 MHz) spectrometer. Analytical samples were routinely dried in vacuo at room temperature. Microanalytical data were recorded on a Perkin-Elmer 2400 Series II C, H, N analyzer. ESIMS(+) mass spectrum of $\mathbf{3}$ was measured with a Waters Micromass Q-Tof micro instrument. Column chromatography was performed with silica gel (100200 mesh) and TLC with silica gel G made of SRL Pvt. Ltd. Petroleum ether used had the boiling range of $60-80^{\circ} \mathrm{C} .{ }^{1} \mathrm{H}$ and ${ }^{13} \mathrm{C}$ NMR and mass spectra of different compounds can be found in the Supplementary Material.

3.1. 1,2-Bis(bromomethyl)benzene. This compound was prepared from $o$-xylene by benzylic bromination with NBS [NBS (2.2 equiv.), ( $\mathrm{PhCOO})_{2}$ (trace), refluxed in $\mathrm{CCl}_{4}, 12 \mathrm{~h}$, yield: 83\%), m.p. $94^{\circ} \mathrm{C}$ (lit. [27] 92-96 $\left.{ }^{\circ} \mathrm{C}\right) ;{ }^{1} \mathrm{H} \mathrm{NMR}\left(\mathrm{CDCl}_{3}\right): \delta 4.66$ (br. s, $4 \mathrm{H},-\mathrm{CH}_{2}-\mathrm{Br}$ ), 7.29-7.31 (m, 2H, Ar-H), 7.33-7.38 (m, $2 \mathrm{H}, \mathrm{Ar}-\mathrm{H})$.

3.2.1,2-Bis(2-formylphenoxymethyl)benzene(1). A mixture of salicylaldehyde (2 mmol) and 1,2-bis(bromomethyl)benzene
( $1 \mathrm{mmol})$ was refluxed in methanolic $\mathrm{KOH}(5 \%, 25 \mathrm{~mL})$ for $7 \mathrm{~h}$. Removal of methanol by distillation and addition of water followed by extraction with ethyl acetate gave crude alkylation product $\mathbf{1}$, which was purified by rapid column chromatography followed by crystallization from $\mathrm{CHCl}_{3}$ petroleum ether (yield: 66\%). The physical and spectral data of 1 were as follows: colourless needles, m.p. $118-120{ }^{\circ} \mathrm{C} ;{ }^{1} \mathrm{H}$ $\mathrm{NMR}\left(300 \mathrm{MHz}, \mathrm{CDCl}_{3}\right): \delta 5.31$ (br. s, $\left.4 \mathrm{H}, 2 \times-\mathrm{OCH}_{2}-\right), 7.05$ (dt, $4 \mathrm{H}, J=7.2$ and $1.5 \mathrm{~Hz}$ ), 7.42-7.45 (m, 2H, ArH), 7.50-7.57 (m, $4 \mathrm{H}), 7.82(\mathrm{dd}, 2 \mathrm{H}, J=7.8$ and $1.8 \mathrm{~Hz}$ ), and 10.45 (br. s, $2 \mathrm{H}$, $2 \times-\mathrm{CHO})$.

3.3. 1,2-Bis(2-acetylphenoxymethyl)benzene (2). A mixture of $o$-hydroxyacetophenone ( $2 \mathrm{mmol}), 1,2$-bis(bromomethyl) benzene $(1 \mathrm{mmol})$ and anhydrous $\mathrm{K}_{2} \mathrm{CO}_{3}(3 \mathrm{~g}$.) was refluxed in dry acetone for $12 \mathrm{~h}$. Usual work-up followed by purification of the resulting crude material by column chromatography over silica gel afforded pure 2 (yield: $78 \%$ ). The physical and spectral data of $\mathbf{2}$ were as follows: colourless needles $\left(\mathrm{CHCl}_{3}\right.$-petroleum ether), m.p. $74^{\circ} \mathrm{C} ;{ }^{1} \mathrm{H} \mathrm{NMR}(300 \mathrm{MHz}$, $\mathrm{CDCl}_{3}$ ): $\delta 2.53\left(\mathrm{~s}, 6 \mathrm{H}, 2 \times-\mathrm{COCH}_{3}\right), 5.27$ (br. s, $4 \mathrm{H},-\mathrm{OCH}_{2}$ ), $7.03(\mathrm{dt}, 4 \mathrm{H}, J=8.4$ and $1.8 \mathrm{~Hz}), 7.40-7.46(\mathrm{~m}, 4 \mathrm{H}), 7.54(\mathrm{dt}$, $2 \mathrm{H}, J=8.4$ and $1.8 \mathrm{~Hz})$, and $7.71(\mathrm{dd}, 2 \mathrm{H}, J=7.8$ and $1.8 \mathrm{~Hz})$.

3.4. (19E,43E)-2.11.27.36-Tetroxaheptacyclo[44.4.0.0 $0^{4,9} \cdot 0^{12,17}$. $\left.0^{21,26} \cdot 0^{29,34} \cdot 0^{37,42}\right]$ pentaconta-1(46), 4(9),5,7,12(17),13,15,19,21, 23,25,29,31,33,37, 39,41,43,47,49-icosaene-18,45-dione (3). A mixture of the dialdehyde $\mathbf{1}(1 \mathrm{mmol})$ and the diketone $\mathbf{2}$ $(1 \mathrm{mmol})$ was dissolved in a $\mathrm{KOH}$ solution $(10 \%, 75 \mathrm{~mL})$ in $\mathrm{MeOH}-\mathrm{H}_{2} \mathrm{O}(3: 1)$ and the mixture was stirred at room temperature. A precipitate began to be formed after $c a .5 \mathrm{~h}$ of stirring. The stirring was continued for $72 \mathrm{~h}$ and then the solid was collected. The solid thus obtained was almost pure 

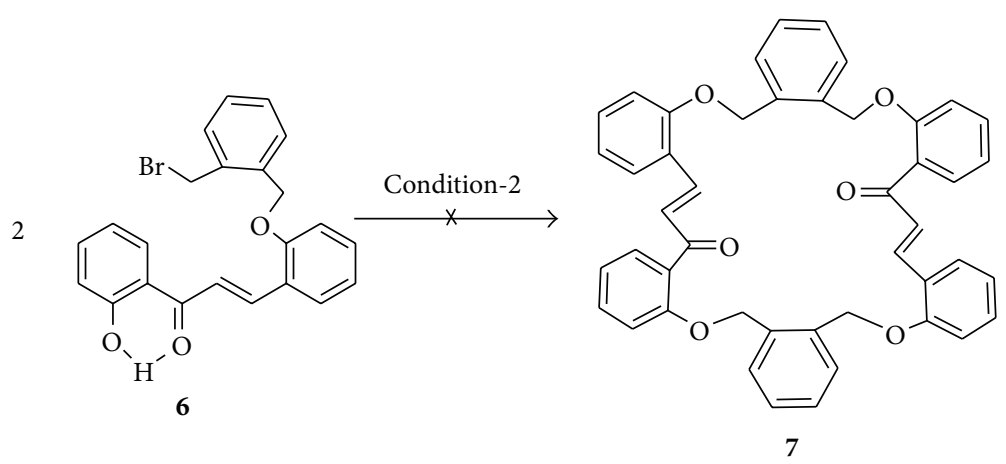

Scheme 3: A possible way of formation of macrocyclic bischalcone from 6.

and it was further purified by column chromatography over silica gel followed by crystallization from $\mathrm{CHCl}_{3}$-petroleum ether (yield: 49\%). The analytical and spectral data of the macrocyclic product 3 were as follows: light yellow cubes; m.p. $205-207^{\circ} \mathrm{C}$; IR $\left(\mathrm{KBr}, \mathrm{cm}^{-1}\right)$ : $1598(\mathrm{C}=\mathrm{O}), 1567,1485$, $1446,1384 \mathrm{~cm}^{-1} ;{ }^{1} \mathrm{H}$ NMR $\left(300 \mathrm{MHz}, \mathrm{CDCl}_{3}\right): \delta 4.85(\mathrm{~s}, 4 \mathrm{H}$, $\left.-\mathrm{O}-\mathrm{CH}_{2}-\right), 5.06\left(\mathrm{~s}, 4 \mathrm{H},-\mathrm{CH}_{2}-\mathrm{O}-\right), 6.77$ (d, $4 \mathrm{H}, J=7.2 \mathrm{~Hz}$ ), $6.80(\mathrm{t}, 2 \mathrm{H}, J=7.5 \mathrm{~Hz}), 6.97(\mathrm{t}, 4 \mathrm{H}, J=7.8 \mathrm{~Hz}), 7.18-7.26$ $(\mathrm{m}, 10 \mathrm{H}), 7.27(\mathrm{~d}, 2 \mathrm{H}, J=16.2 \mathrm{~Hz}, 2 \times \mathrm{H}-\alpha), 7.38(\mathrm{dt}, 2 \mathrm{H}, J$ $=7.5$ and $1.5 \mathrm{~Hz}$ ), $7.47(\mathrm{dd}, 2 \mathrm{H}, J=8.4$ and $1.5 \mathrm{~Hz}), 7.70(\mathrm{~d}$, $2 \mathrm{H}, J=16.2 \mathrm{~Hz}, 2 \times \mathrm{H}-\beta) ;{ }^{13} \mathrm{C}$ NMR $\left(75 \mathrm{MHz}, \mathrm{CDCl}_{3}\right): \delta$ $68.23,68.48,112.47,112.75,121.04,121.21,123.98,127.65,128.10$, $128.11,128.48,129.40,129.60,130.10,130.21,131.47,132.23$, 133.81, 134.42, 140.17, 156.42, 157.10, $194.64(\mathrm{C}=\mathrm{O})$; MS (TOF MS ES $\left.{ }^{+}\right): m / z 707.18(\mathrm{M}+\mathrm{Na})^{+}, 685.19(\mathrm{M}+\mathrm{H})^{+}$. Elemental analysis: Calcd. for $\mathrm{C}_{46} \mathrm{H}_{36} \mathrm{O}_{6}: \mathrm{C}, 80.68 ; \mathrm{H}, 5.30$. Found: $\mathrm{C}$, 80.56; H 5.42\%.

3.5. 2,2'-Dihydroxychalcone (4). This chalcone was prepared by condensation of $o$-hydroxyacetophenone and salicylaldehyde with aqueous alkali, m.p. $162-164^{\circ} \mathrm{C}$ (lit. [28] $\left.168^{\circ} \mathrm{C}\right) .{ }^{1} \mathrm{H}$ $\operatorname{NMR}\left(300 \mathrm{MHz}, \mathrm{CDCl}_{3}\right): \delta 5.74$ (br. s, $\left.1 \mathrm{H}, 2-\mathrm{OH}\right), 6.88$ (br. $\mathrm{d}, 1 \mathrm{H}, J=8.1 \mathrm{~Hz}), 6.94-7.07(\mathrm{~m}, 3 \mathrm{H}), 7.32(\mathrm{dt}, 1 \mathrm{H}, J=7.8$ and $1.8 \mathrm{~Hz}), 7.52(\mathrm{dt}, 1 \mathrm{H}, J=7.5$ and $1.5 \mathrm{~Hz}), 7.63(\mathrm{dd}, 1 \mathrm{H}, J=7.8$ and $1.9 \mathrm{~Hz}), 7.87(\mathrm{~d}, 1 \mathrm{H}, J=15.6 \mathrm{~Hz}, \mathrm{H}-\alpha), 7.96(\mathrm{dd}, 1 \mathrm{H}, J=8.1$ and $1.5 \mathrm{~Hz}), 8.21(\mathrm{~d}, 1 \mathrm{H}, J=15.6 \mathrm{~Hz}, \mathrm{H}-\beta), 12.92\left(\mathrm{~s}, 1 \mathrm{H}, 2^{\prime}-\mathrm{OH}\right)$.

3.6. (19E)-2.11-Dioxatetracyclo[19.4.0.0 $\left.0^{4,9} \cdot 0^{12,17}\right]$ pentacosa1(25),4(9),5,7,12(17),13,15,19,21,23-decaen-18-one (5). To a mixture of $4(1 \mathrm{mmol})$ and 1,2-bis(bromomethyl)benzene $(1 \mathrm{mmol})$ in dry acetone $(25 \mathrm{~mL})$, anhydrous $\mathrm{K}_{2} \mathrm{CO}_{3}(3 \mathrm{~g})$ was added and the mixture was refluxed with stirring for $12 \mathrm{~h}$. Usual work-up of the reaction mixture followed by chromatography of the crude product over silica gel using petroleum ether-ethyl acetate $(90: 10, \mathrm{v} / \mathrm{v})$ gave pure 5 as light yellow crystals (yield: $57 \%$ ), m.p. $160-162^{\circ} \mathrm{C}$, IR (KBr) $\mathrm{cm}^{-1}: 3028,2903,1585,1562,1470,1453,1436,1297,1249,1152$, 1058, 960, 745. ${ }^{1} \mathrm{H}$ NMR (300 MHz, $\left.\mathrm{CDCl}_{3}\right): \delta 5.28(\mathrm{~s}, 4 \mathrm{H}, 2$ $\left.\times \mathrm{ArCH}_{2} \mathrm{O}-\right), 7.01-7.10(\mathrm{~m}, 2 \mathrm{H}), 7.11(\mathrm{~d}, 1 \mathrm{H}, J=16.5 \mathrm{~Hz}, \mathrm{H}-\alpha)$, $7.23-7.38(\mathrm{~m}, 7 \mathrm{H}), 7.45-7.51(\mathrm{~m}, 2 \mathrm{H}), 7.58(\mathrm{dd}, 1 \mathrm{H}, J=7.5$ and $1.8 \mathrm{~Hz}$, proton ortho to $\mathrm{C}=\mathrm{O}), 7.66(\mathrm{~d}, 1 \mathrm{H}, J=16.5 \mathrm{~Hz}, \mathrm{H}-\beta)$, ${ }^{13} \mathrm{C}$ NMR $\left(75 \mathrm{MHz} \mathrm{CDCl}_{3}\right): \delta 68.65,71.70,113.51,119.01$,
$121.67,123.46,128.43,128.81,129.19,129.77,129.79,129.87$, $130.68,130.88,131.89,132.62,135.18,135.29,141.56,156.71$, 156.97, 195.23. MS (TOF MS ES $\left.{ }^{+}\right): m / z(\mathrm{M}+\mathrm{Na})^{+} 365.00$. Elemental analysis: Calcd. for $\mathrm{C}_{23} \mathrm{H}_{18} \mathrm{O}_{3}$ : C, 80.68; $\mathrm{H}, 5.30$. Found: C, 80.45; H, 5.44\%.

\section{Conclusion}

Thus, we report very simple syntheses of two new benzofused macrocycles incorporating chalcone moiety by the use of very common starting materials. The compounds may find important applications.

\section{Conflict of Interests}

The authors declare that there is no conflict of interests regarding the publication of this paper.

\section{Acknowledgments}

Financial assistance from the DST-PURSE program, Department of Chemistry, and the UGC-UPE-II program to Jadavpur University is gratefully acknowledged. The authors also acknowledge the DST-FIST program to the Department of Chemistry, Jadavpur University, for providing the NMR spectral data. Rina Mondal and Saheli Sarkar are thankful to the UGC and Swati Samanta is thankful to the CSIR, New Delhi, for their research fellowships.

\section{References}

[1] D. N. Dhar, The Chemistry of Chalcones and Related Compounds, John Wiley \& Sons, New York, NY, USA, 1981.

[2] A. Solankee, S. Lad, S. Solankee, and G. Patel, "Chalcones, pyrazolines and aminopyrimidines as antibacterial agents," Indian Journal of Chemistry B, vol. 48, no. 10, pp. 1442-1446, 2009.

[3] L. Svetaz, A. Tapia, S. N. López et al., "Antifungal chalcones and new caffeic acids esters from Zuccagnia punctata acting against soybean infecting fungi," Journal of Agricultural and Food Chemistry, vol. 52, no. 11, pp. 3297-3300, 2004.

[4] C. E. Gutteridge, J. V. Vo, C. B. Tillett et al., "Antileishmanial and antimalarial chalcones: synthesis, efficacy and cytotoxicity 
of pyridinyl and naphthalenyl analogs," Medicinal Chemistry, vol. 3, no. 2, pp. 115-119, 2007.

[5] S. K. Awasthi, N. Mishra, S. K. Dixit et al., "Short report: antifilarial activity of 1,3-diarylpropen-1-one: effect on glutathiones-transferase, a phase ii detoxification enzyme," The American Journal of Tropical Medicine and Hygiene, vol. 80, no. 5, pp. 764768, 2009.

[6] M. J. Alcaraz, A. M. Vicente, A. Araico, J. N. Dominguez, M. C. Terencio, and M. L. Ferrándiz, "Role of nuclear factor- $\kappa \mathrm{B}$ and heme oxygenase- 1 in the mechanism of action of an antiinflammatory chalcone derivative in RAW 264.7 cells," British Journal of Pharmacology, vol. 142, no. 7, pp. 1191-1199, 2004.

[7] Z. Nowakowska, "A review of anti-infective and antiinflammatory chalcones," European Journal of Medicinal Chemistry, vol. 42, no. 2, pp. 125-137, 2007.

[8] J.-H. Jeon, S.-J. Kim, C. G. Kim, J.-K. Kim, and J.-G. Jun, "Synthesis of biologically active chalcones and their antiinflammatory effects," Bulletin of the Korean Chemical Society, vol. 33, no. 3, pp. 953-957, 2012.

[9] F. Hayat, E. Moseley, A. Salahuddin, R. L. van Zyl, and A. Azam, "Antiprotozoal activity of chloroquinoline based chalcones," European Journal of Medicinal Chemistry, vol. 46, no. 5, pp. 1897-1905, 2011.

[10] B. Baviskar, S. Patel, S. S. Khadebadi, and M. Shiradkar, "Design and synthesis of some novel chalcones as potent antimicrobial agent," Asian Journal of Research in Chemistry, vol. 1, no. 2, pp. 67-69, 2008.

[11] A. Solankee, K. Kapadia, M. Soković, I. Doytchinova, and A. Geronikaki, "Synthesis of some new S-triazine based chalcones and their derivatives as potent antimicrobial agents," European Journal of Medicinal Chemistry, vol. 45, no. 2, pp. 510-518, 2010.

[12] B. Tiwari, A. S. Pratapwar, A. R. Tapas, S. R. Butle, and B. S. Vatkar, "Synthesis and antimicrobial activity of some chalcone derivatives," International Journal of ChemTech Research, vol. 2, no. 1, pp. 499-503, 2010.

[13] Y. R. Prasad, A. L. Rao, and R. Rambabu, "Synthesis and antimicrobial activity of some chalcone derivatives," E-Journal of Chemistry, vol. 5, no. 3, pp. 461-466, 2008.

[14] N. A. Begum, N. Roy, R. A. Laskar, and K. Roy, "Mosquito larvicidal studies of some chalcone analogues and their derived products: structure-activity relationship analysis," Medicinal Chemistry Research, vol. 20, no. 2, pp. 184-191, 2011.

[15] S. Genovese, F. Epifano, M. Curini, M. Dudra-Jastrzebska, and J. J. Luszczki, "Prenyloxyphenylpropanoids as a novel class of anticonvulsive agents," Bioorganic and Medicinal Chemistry Letters, vol. 19, no. 18, pp. 5419-5422, 2009.

[16] J.-H. Wu, X.-H. Wang, Y.-H. Yi, and K.-H. Lee, "Anti-AIDS agents 54. A potent anti-HIV chalcone and flavonoids from genus Desmos," Bioorganic and Medicinal Chemistry Letters, vol. 13, no. 10, pp. 1813-1815, 2003.

[17] S. Shibata, "Anti-tumorigenic chalcones," Stem Cells, vol. 12, no. 1, pp. 44-52, 1994.

[18] V. R. Solomon and H. Lee, "Anti-breast cancer activity of heteroaryl chalcone derivatives," Biomedicine \& Pharmacotherapy, vol. 66, no. 3, pp. 213-220, 2012.

[19] A. Voskiene and V. Mickevičius, "Cyclization of chalcones to isoxazole and pyrazole derivatives," Chemistry of Heterocyclic Compounds, vol. 45, no. 12, pp. 1485-1488, 2009.

[20] G. Sandeep, Y. S. Ranganath, S. Bhasker, and N. Rajkumar, "Synthesis and biological screening of some novel Coumarin derivatives," Asian Journal of Research in Chemistry, vol. 2, no. 1, pp. 46-48, 2009.
[21] K. A. Brien, R. K. Bandi, A. K. Behera et al., "Design, synthesis and cytotoxicity of novel chalcone analogs derived from 1cyclohexylpyrrolidin-2-one and 2,3-dihydrobenzo[f]chromen1-one," Archiv der Pharmazie-Chemistry in Life Sciences, vol. 345, no. 5, pp. 341-348, 2012.

[22] V. Satam, R. K. Bandi, A. K. Behera et al., "Design, synthesis, and cytotoxicity of novel 3-arylidenones derived from alicyclic ketones," Chemical Biology and Drug Design, vol. 78, no. 4, pp. 700-708, 2011.

[23] V. Satam, R. K. Bandi, A. K. Behera et al., "Design, synthesis and cytotoxicity of chalcone analogs derived from 2-phenylimino3-phenylthiazolidin-4-one," Letters in Drug Design and Discovery, vol. 8, no. 8, pp. 704-708, 2011.

[24] R. Matsushima, S. Fujimoto, and K. Tokumura, "Dual photochromic properties of 4-dialkylamino-2-hydroxychalcones," Bulletin of the Chemical Society of Japan, vol. 74, no. 5, pp. 827832, 2001.

[25] K. Rurack, M. L. Dekhtyar, J. L. Bricks, U. Resch-Genger, and W. Rettig, "Quantum yield switching of fluorescence by selectively bridging single and double bonds in chalcones: involvement of two different types of conical intersections," Journal of Physical Chemistry A, vol. 103, no. 48, pp. 9626-9635, 1999.

[26] R. Mondal, T. K. Mandal, and A. K. Mallik, "Simple synthesis of a new family of 22- to 28-membered macrocycles containing two chalcone moieties," Arkivoc, vol. 2012, no. 9, pp. 95-110, 2012.

[27] http://www.chemspider.com/Chemical-Structure.60032.html.

[28] A. R. Alcantara, J. M. Marinas, and J. V. Sinisterra, "Synthesis of $2^{\prime}$-hydroxychalcones and related compounds in interfacial solid-liquid conditions," Tetrahedron Letters, vol. 28, no. 14, pp. 1515-1518, 1987. 

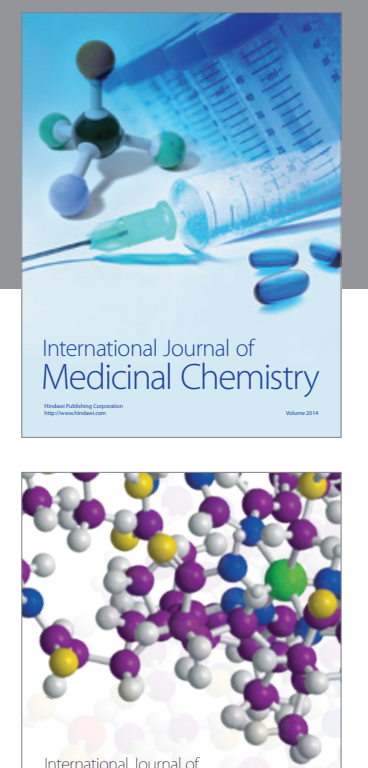

\section{Carbohydrate} Chemistry

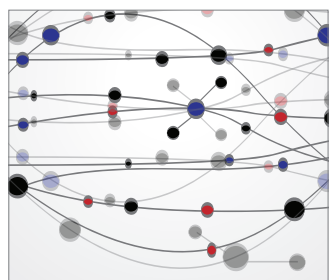

The Scientific World Journal
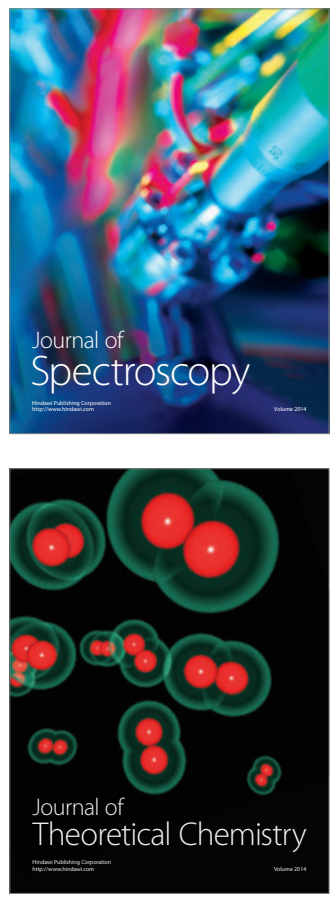
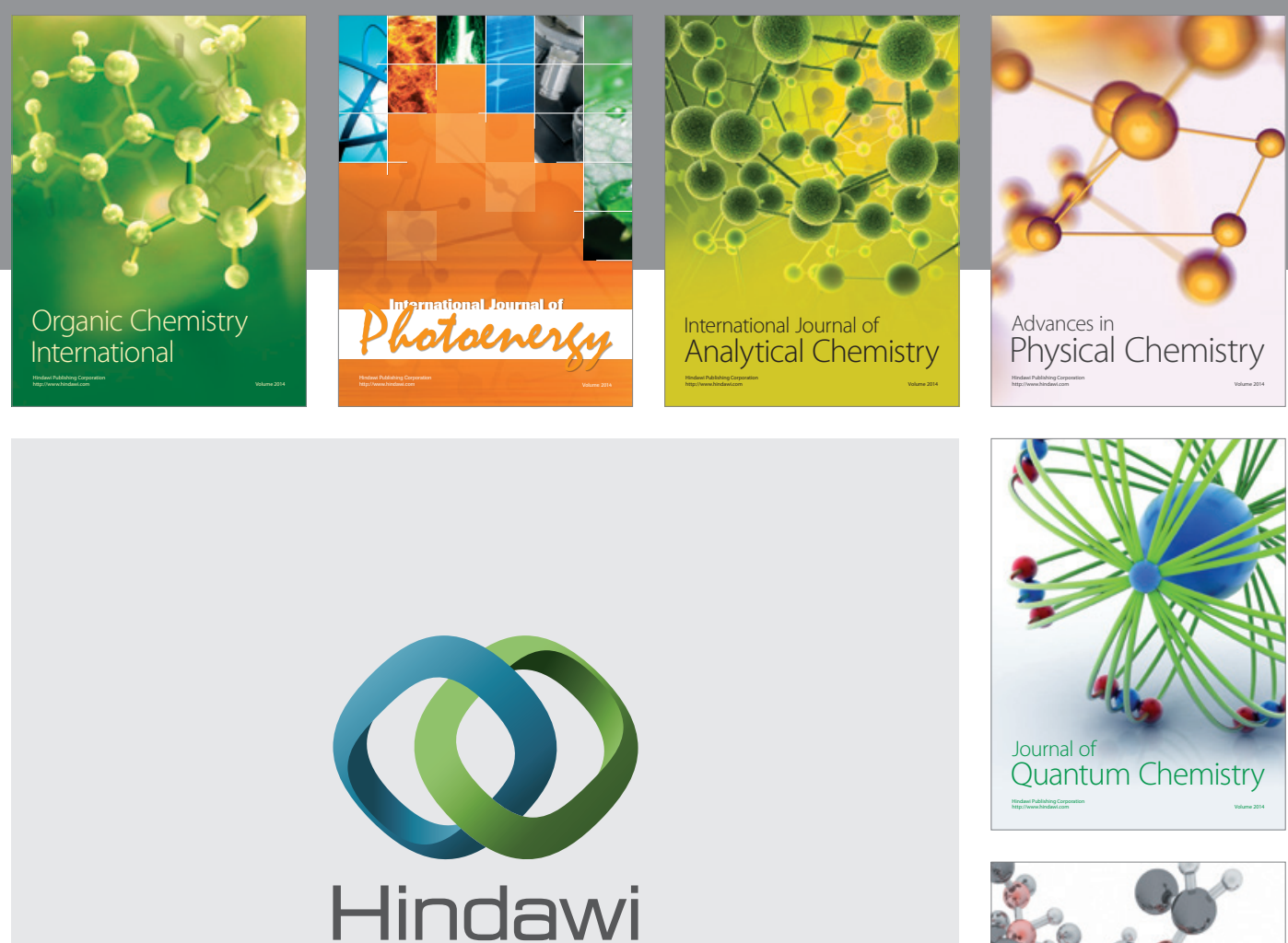

Submit your manuscripts at

http://www.hindawi.com

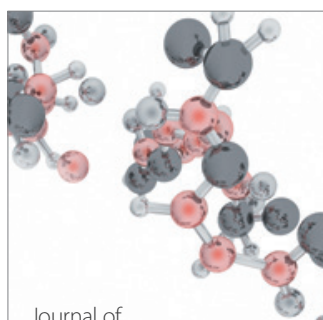

Analytical Methods

in Chemistry

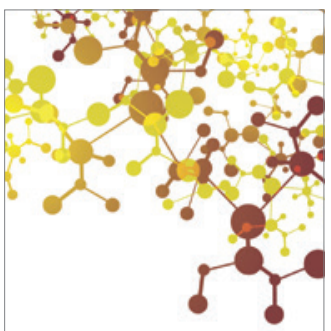

Journal of

Applied Chemistry

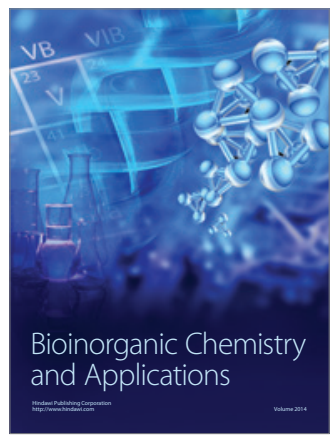

Inorganic Chemistry
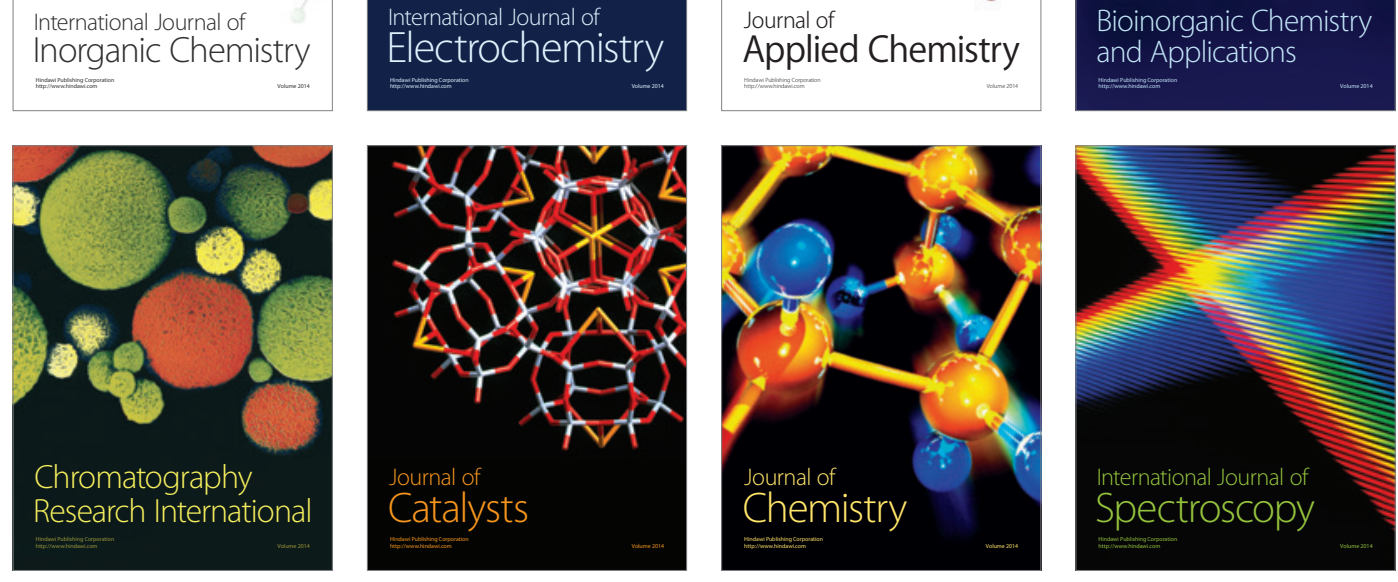